\title{
Idealist Model for Sustainable Tourism Development in the Way Bekhak Ecotourism, Tanggamus Regency
}

\author{
Junaidi \\ Sociology Department \\ Lampung University \\ Lampung, Indonesia \\ junaidi@fisip.unila.ac.id
}

\author{
Prasetya Nugeraha \\ Business Administration Departemen \\ Lampung University \\ Lampung, Indonesia \\ Prasetya.nugeraha18@gmail.com
}

\author{
Muhammad Guntur Purboyo \\ Sociology Department \\ Lampung University \\ Lampung, Indonesia \\ muhammadguntur@fisip.unila.ac.id

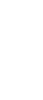

Erika Aryanti

Erika Aryanti
Sociology Department

Lampung University

Lampung, Indonesia

erikarynti12@gmail.com

\begin{abstract}
The existence of several cases of community exclusion due to the tourism industry has attracted researchers to examine the idealistic model of sustainable ecotourism development for communities in the Way Bekhak ecotourism area, Tanggamus Regency. This study aims to build a tourism model that is following the characteristics of the surrounding community as a basis for development so that people do not feel excluded from their environment. This study uses a literature review research method or literature study. Where this study will collect various sources relevant to the object of research. Thus, this study will contain theories, concepts, and/or cases that are relevant to the problem being studied. Therefore, researchers try to describe various concepts and theoretical sources in the development of sustainable tourism. Especially those that want to be implemented in the Way Bekhak ecotourism area, Tanggamus Regency. This study also uses secondary data obtained from various library sources. This research is expected to produce an idealistic model of sustainable ecotourism development that is oriented to the community, especially in the Way Bekhak ecotourism area, Tanggamus Regency. The goal is to foster popular innovation in building a model of sustainable tourism in the ecotourism area.
\end{abstract}

Keywords-idealistic model, development, ecotourism, sustainable, community

\section{INTRODUCTION}

One of the aspects of tourism that is closest to driving the economy of people in rural areas, namely by utilizing natural resources to serve as ecotourism. The natural environment in rural areas usually has a high selling value if used in the tourism sector. This is because ecotourism in rural areas makes the natural and cultural environment a tourist attraction and is used as an industrial object [1]. Thus, rural area tourism which is included in the ecotourism category can be used as village tourism. Of course, this has a fairly important selling point in moving the economy of the community around the area. In fact, according to the World Tourism Organization (WTO) shows that from the 1990s to the present, the global, regional, and national communities are more interested in nature tourism. This means that the public's anomie in traveling back to nature (back to nature) so that both local and foreign tourists look for unspoiled places to visit [2]. Therefore, ecotourism becomes a sustainable economic field if managed properly.

The not yet optimal use of local ecotourism objects as a means of improving the community's economy is a problem that needs to be fixed as soon as possible so that it can have a positive impact on the socio-economic life of the community. As happened in Way Bekhak ecotourism has not been able to be optimized as well as possible as an ecotourism industry which has a much more positive impact on the surrounding community. Tourism objects around Way Bekhak ecotourism can grow the economy and community welfare because they have social and natural capital that can be used as selling points in the ecotourism industry.

Failure to develop the tourism sector can occur when parties with an interest in managing ecotourism are not able to find an ideal model for more sustainable ecotourism development. All objects around ecotourism can be utilized and mobilized in designing an ecotourism model that can later be utilized sustainably. In addition, another factor of the failure in 
the development of the tourism sector, namely the inability of local governments to manage the social system as an object as well as a subject of development. The inability to manage the community as the subject of development means neglecting the community as social capital that can increase the development of tourism areas [3]. Therefore, one of the key factors in finding a sustainable ecotourism model is by optimizing the role of the community as agents of change. The community can be used as social capital in driving ecotourism to be better and more useful in driving the local economy. Hizbullah (2006) even mentions that the success of an area's development depends on how to manage the community as development agents [4].

However, some of the current realities of society are often not involved in managing their nature in the ecotourism sector. Even if they are involved it is only a complement to the economy and they are not given room for further discussion on how to manage their environment. Meanwhile, their environment is used as an ecotourism object that can bring benefits to the country. In fact, in Junaidi's research (2018), it was found that people living in the area around ecotourism were excluded from their environment [5]. Whereas in the concept of sustainable ecotourism, the community can be used as a protective agent and conservation of tourist attractions, because their lives depend on nature which is used as a tourist spot [2].

In addition, on the other hand, there are cases where the natural environment can be damaged by ecotourism making this industry unable to survive and be sustainable. This is of course because ecotourism is a form of industry that sells its natural beauty as its main product. When the natural environment changes for the worse, it will be abandoned by tourists who are the main consumers in the ecotourism sector. What is described by Qodriyatun's research (2018) provides a lesson on how management should be considered [6]. Damage to ecosystems that hurt the survival of living things around tourism objects is an illustration that needs to be considered in how to manage ecotourism so that it continues to be sustainable. That is, having a common understanding of the importance of managing ecosystems in ecotourism areas is a fixed price in ecotourism management so that success in managing ecotourism can be achieved properly. Therefore, to achieve this success comprehensively, it is necessary to describe a model of sustainable ecotourism development. Where the model must be able to see social capital and natural environmental capital as the main capital in achieving success. In this perspective, these two assets can be described as the key capital for the success of a sustainable ecosystem. For example, social capital can be seen from the community capital owned by a community in an area.

Of course, the community capital does not stand alone but is supported by its human capital such as education, knowledge, expertise, health, and so on.
Then, capital of natural resources, such as sea waters. Furthermore, productive economic capital in the form of economic assets, financial, and so forth. Finally, social capital, namely community participation in developing its potential to take advantage of existing networks [3]. Then the natural environment capital which can be in the form of all living things and/or nonliving creatures other than humans who are around ecotourism, such as water, plants, animals, rocks, and so on. Thus, incorporating these two eco-tourism capitals into a single unit can be used as a model for sustainable ecotourism. Where the model has not been described, it has not even been able to be described by previous studies in building an ideal model of sustainable ecotourism. These studies are for example the Winingsih research (2020) which only puts the economy as a way to develop sustainable tourism [7]. Furthermore, Lubis's (2018) research only looks at the role of youth in tourism institutions, so it can be ascertained that there are community components that are not involved in managing tourism [8]. Then, Haryanto's research (2013) looks at the sustainable tourism development model as an effort to create a new leading economy [9]. This study only looks at how the concept of tourism with a new leading economy approach where this approach is more oriented to the economic sector, even though the socio-cultural sector is also important.

In the research of Febriana and Pangestuti (2018), they only look at the impact of tourism on the social, cultural, and economic life of the community [10]. However, this research has not been able to provide a model of sustainable tourism comprehensively and sustainably. Sutiarso's research (2017) on the development of sustainable tourism through ecotourism [11]. It gives a little description but has not been able to describe the position of the community in creating sustainable tourism. Then the research of Wisnawa, Saharjo, and Wijayanti (2019) regarding public perceptions of the behavior of Chinese tourists towards the sustainability of Bali tourism with the Sapta Pesona approach [12]. Nor has it been able to provide an idealistic model in sustainable development. Then research Utari and Kampana (2014) planning tourism facilities (tourism amenities) Pandawa Beach Kutuh Village, South Kuta Badung, which also does not describe how a sustainable ecotourism model [13]. Furthermore, Khairunnisa's research (2020) is still unable to lay down how the community plays an active role in maintaining their ecological and social impacts [14]. Furthermore, the research of Situngkir, Lubis, and Kkadir (2020) only looks at opportunities for implementing collaborative management in the development of the China City site area as a tourism potential in Medan City [15]. Then, Andina's research (2018) only looks at social carrying capacity in terms of the tourism paradigm, implementation capacity, weak supervision and implementation as well as training, and only looks at political factors, so it has not been able to provide an overview of how the community places 
itself and plays a role in tourism as a whole [16]. Thus, looking at the previous studies, we have not been able to see an ecotourism model whose basic idea was indeed developed by the community around the area. This needs to be done because, they are more aware of their nature, so it will be more sustainable.

Departing from the description above, this research will place itself as a part that wants to describe how the participation of every component of society in creating a model of sustainable economic development. Thus, in the regional management and development stage, all communities feel an interest in maintaining and preserving their tourism areas. Thus, there is a need for research on the idealistic perception of the community in building a model of sustainable tourism in ecotourism areas. The area that is used as a locus to describe the idealistic perception of the community in building a sustainable tourism model in ecotourism areas is the Way Bekhak ecotourism area. The determination of this locus is because Way Bekhak ecotourism is located in Tanggamus Regency, Lampung Province, and is ecotourism that is still not optimal in its management, both by the government and by the village community. This is evidenced by the results of the author's initial interview and observation study in May 2021 which showed that the Way Bekhak ecotourism has not developed its culture and nature as an ecotourism industry more optimally.

\section{METHOD}

The method in this study uses library research (library research). Sources of data in this study, namely, were derived from primary and secondary sources. Primary sources were obtained from observations, documentation, and simple interviews. Then secondary sources are carried out by collecting various library sources that are relevant to the object of research. These sources can be in the form of textbooks, scientific journals, results of previous research, magazines, statistical references, and various sources of information either from electronic or print media as well as other sources relevant to the object of research. In data collection techniques in this study, the researcher must first know the area of the research object and then analyze the area to find out what problems occur in the research object. Of course, this is part of primary data collection. After the researcher analyzes the research object, the researcher collects data and collects various data needed in solving the problem to be studied, in the form of all the data needed as part of secondary data collection. The data analysis technique in this study is to collect various data sources, both primary and secondary. Then the researcher analyzed the data obtained which was then systematically described the facts obtained when the research was conducted to conclude.

\section{RESUlT AND DISCUSSION}

\section{A. Research Results from Ecotourism Objects}

Way Bekhak ecotourism is located in Sukaraja Village, Gunung Alip District, Tanggamus Regency. Ekowiasta Way Bekhak makes natural beauty its industrial object. Natural resources in Way Bekahk ecotourism are springs and streams from springs that create a natural flow on the surface of rocks and soil. Way Bekhak ecotourism not only offers the beauty of naturally created springs and water streams but also offers tours of lettuce farming planted by the people around Way Bekhak. At first, it was used to irrigate the rice fields of farmers in Sukaraja Village and villages under Sukaraja Village, Gunung Alip District. However, over time, Way Bekhak ecotourism is used as a place to travel by people around Tanggamus Regency as well as other regencies or cities in Indonesia.

\section{B. Community Social Capital as part of the Sustainable Ecotourism Model}

The values that are built in society are constructed through understanding that is carried out through interactions within the community. These interactions can be direct or indirect carried out by some individuals in the community, and that is also an option. At least the choice is to strengthen social networks among each individual's community. In addition, in the reality of mechanical society, Durkheim (2012) sees interaction as a way to achieve happiness, because through this interaction they perceive or are considered part of their group [17]. This is certainly the nature of community solidarity, namely solidarity with full ties with having the same and strong awareness. Of course, this can be seen in the form of traditional societies, because the bonds of community solidarity are strongly influenced by how they interact with each other [18]. Therefore, the ties they have can be used as the basic capital in developing ecotourism areas, including Way Bekhak ecotourism. This basic capital can be seen as social capital which can later be utilized and mobilized in creating sustainable ecotourism development.

Social capital is defined as a representation of the resources owned by the community arising from relationships between individuals and groups that can help them in their work, to achieve their goals for the common good [19]. Several resources owned by individuals and groups in the community are assumed to be a network that has the potential to build relationships in creating a network that can make it easier for them to work and carry out other activities [20]. By looking at this, people who live in ecotourism areas in a social structure have capital that can be used. The kinship that is built in the local community in ecotourism areas can be said as a network that can be categorized as a network in social capital. This is because the existing network system in community kinship becomes potential in developing tourism areas. Thus, social relations will create a network that can 
facilitate people living in ecotourism areas in developing the tourism sector in their area.

Cloete (2014) reveals that social capital has two characteristics, namely, first, social capital is seen as a public good that is never privately owned by people who feel the benefits [21]. Second, social capital is seen as man-made capital that is not natural (artificial capital). This capital refers to something made by humans to make it easier for them to carry out everything and can be useful in the future. This capital is in the form of physical capital, human capital, and social capital. Therefore, two components of social capital can be distinguished, but not separated from each other, namely structure and content [19]. The structural aspect refers to a formalized pattern of connections between networks or participation in voluntary organizations. Then the content aspect refers to the relational aspects related to human assets in a relationship from the network. Lewicky \& Brinsfield (2009) explain that from the two components that are distinguished but cannot be separated in relationships, the relational dimension includes the quality of individual connections that form a wider network and also focuses on trust, justice, and social norms, which lead to obligations [22]. And the hope of creating reciprocal relationships [21].

Bartkus \& Davis (2009) and Cloete (2014) state that there are two main approaches seen in social capital, namely functional and descriptive approaches [19,21]. A functional approach is part of a social organization owned by the community in the form of beliefs and norms which are then developed in a network that can increase efficiency in their work, making it easier for them to coordinate with each other [23]. The OECD (2001) sees it as a shared network between individuals or groups in society by referring to shared norms, values, and understanding to facilitate cooperation between groups [24]. From a functional approach, placing social capital as a tool in facilitating the community to achieve something desired. This is because social capital is placed as a network owned by the community. Functionally the network can make it easier for people to work. The existing network instruments can be utilized by the Way Bekhak ecotourism area in optimizing itself in regional development. Social capital owned by the community around Way Bekhak ecotourism can functionally be used as a medium of change in developing their territory. Ecotourism can be one of the development sectors that can be utilized in the welfare of the community because this sector has the potential as an economic gateway for the community, as well as a gateway in promoting their culture to the wider community.

Furthermore, descriptively, social capital is seen as a resource owned by the community that is embedded and available in the network they have and is built through relationships between individuals and their social units [25]. This approach views social capital as a resource that is described through a network owned by the community. The network exists and is hidden in the social relations of the community. In the realm of the reality of ecotourism objects in the area around Way Bekhak ecotourism, the surrounding communities are descriptive of course they have social relationships between individuals and group units. The nature of the description in the social capital owned by the local community around Way Bekhak ecotourism can be described by the social relationships embedded in group units which are illustrated in the "Gontong Royong " nature of the community in completing work together. Therefore, this descriptive approach can be a strength in creating sustainable ecotourism in the Way Bekhak ecotourism area, because this approach places the community as an essential resource that can be utilized in building sustainable ecotourism in the Way Bekhak ecotourism area.

Social capital consists of several aspects of the social structure with its function as a facility in carrying out social actions in the social structure. Social capital is a means of productivity in achieving something desired in the future. Social capital is attached to the structure of the relationship between actors and between actors. The identified function of social capital in the form of a structural aspect is more for actors as a resource that can be used to achieve their interests. The form of social capital depends on two forming elements, namely first, trust from the social environment, meaning that there are obligations that must be paid off, secondly the extent to which these obligations are held in the community. Social structures differ in both dimensions, and actors within the same structure differ in both trust and responsibility [26]. By looking at this, the people of the Way Bekhak ecotourism area structurally have kinship relationships will be able to solve various social problems together through "Gontong Royong " actions. This social action is categorized as social capital as a means of development. Optimizing this action in developing the ecotourism sector will make it easier for local governments to improve their regional performance. Especially in organizing the community as agents of development in their area, so that with the ease of organizing the community all government programs can be achieved. Of course in this case in the ecotourism aspect of the Way Bekhak area.

An important form of social capital is the information potential inherent in social relationships. This information is important in providing a basis for action. However, the acquisition of information is so difficult and expensive. One of the means of information that can be used to find out information is by using social relationships that have a primary purpose or other purposes. Social capital owned by the community can provide value in developing the younger generation in society. This development is obtained from their association with the community and 
institutions that exist in society. Thus, the relationship that exists between members of the community as a forum in fostering their generation to become a capital that can be used for further interests [26]. In reality, people in the Way Bekhak ecotourism area can organize their youth who are members of the Mulimakhanai traditional institution. The youths who are members of the local village organizations are used as the main agents in disseminating information, as well as guardians of the essential eco-tourism sector to continue to be used sustainably. Thus, social capital owned by the community has a form in form of informative potential in social networks [27]. Herreros (2004) sees that trust and networks in social capital are not the same, but are more related to reciprocal obligations that can come from the relationship of trust and information obtained from participation in social networks [28]. Although the participation of members and community groups can create a reliable information network [21].

Social capital has indicators that focus on social relationships in the form of personal relationships and organizational membership that create a network of contacts and support. Community involvement in the Way Bekhak ecotourism area in the public sphere which can be represented by their youth is an important indicator in creating the subjective quality of social relations. This will be a quality that will be felt by community institutions [29]. Requena, Ortega, \& Villaverde (2012) see this as a network that is formed in a relationship in social capital to provide a way for everyone to work together for profit [30]. This can later be seen from the nature of "Gontong Royong" which is always maintained by the community in the Way Bekhak ecotourism area. All agents in the form of individuals, governments, companies, or communities can explore and benefit from the resources placed in the relationship [31]. Therefore, the relationship created in the community will be an advantage in developing an ecotourism area in Way Bekhak. People in the Way Bekhak ecotourism area can explore all the resources in their area by utilizing the network that has been built, both with the government and with the private sector.

The expression of social capital in the form of community participation in all fields such as community involvement in politics, providing assistance to others, or volunteering in promoting development in all sectors including ecotourism. Furthermore, community involvement in work-related organizations (trade unions, professional associations), sports and recreational organizations, religious organizations, community or school-related groups, cultural, educational, and hobby-related groups, or service clubs and fraternal organizations is part of the expression of social capital in society [32]. Therefore, community involvement in these various activities will provide space for the community to develop themselves and create themselves as agents of change in their area.
The government as a policyholder has a role in managing social capital in the community. The role of government in building social capital is widely understood in terms of maintaining the quality of governance in general. The role of the government is also in terms of maintaining all forms of rights owned by community members in the Way Bekhak ecotourism area. Because the government must see the community as social capital that can manage itself. Then protect public safety and reduce poverty and unemployment. Providing health and education services and overcoming things that can weaken the community as social capital [29]. Thus, the people who inhabit the Way Bekhak ecotourism area also have social capital that can be mobilized to increase development. In general, society has values and norms that can be categorized as social capital that can play a role in determining the success of individuals and groups in society [33]. With the social capital they have in the form of values and norms that can form a pattern of relationships and trust and responsibility between community members, they work together to achieve what they want [34].

\section{Combination of social and natural capital to create a sustainable Ecotourism model}

The community in the Way Bekhak ecotourism area has resources in the form of natural springs and beautiful landscapes. Both of these resources are used in the survival of members of the community. The potential of natural resources owned by the community in the Way Bekhak ecotourism area can be used as capital to achieve prosperity. To achieve this, access to information and networks that exist in social capital is a solution in increasing regional development. In addition, the potential for the natural beauty of natural springs and landscapes that have beauty can be an attraction in getting profits. The ecotourism sector development plan as part of utilizing the resources owned by the community in the Way Bekhak ecotourism area is an important matter to be improved by utilizing social capital. The community must be involved in developing the Ecotourism Industry in their area. They must be empowered as best as possible in maintaining and preserving the nature around them.

Ecotourism places nature as the main base in developing tourism activities. This basis is based on environmental conditions that exist in an area or community. Dalem (2002) illustrates that sustainable ecotourism focuses on eco-friendly tourism based on the environment with a focus on helping to increase understanding, appreciation, and conservation of the environment and culture [35]. Important aspects that are used as basic objects in developing ecotourism must always refer to nature conservation and community empowerment. The main principle of ecotourism refers to the preservation of nature and the environment, which will always provide the widest possible space for local communities to play an active role in ecotourism activities [2]. In that sense, ecotourism in Way Bekhak 
must maintain its environment so that it can still be used as an ecotourism industry sector. The ability of the community around the Way Bekahak ecotourism must be able to be developed to maintain the sustainability of their environment. This can be done by empowering all community members as well as possible. The provision of training and practical knowledge must be encouraged following the needs of the ecotourism industry.

In sustainable ecotourism, nature conservation must always be done to protect the ecosystems in ecotourism areas. Nature must be preserved because the natural environment is the basic capital in developing ecotourism. Success in protecting the environment, both natural and social, will be a long-term investment in ecotourism activities. This is because ecotourism can be used as an object in creating jobs for local communities, so it will certainly provide benefits either directly or indirectly to the community or local government [36]. Referring to this, the government and the community must work together in preserving their environment. The environmental form is an investment for the sustainability of Way Bekhak ecotourism. Sustainable development must be the basis for the development of Way Bekhak ecotourism. Way Bekhak ecotourism must always be able to attract tourists so that the ecotourism industry in the area can run well. If the ecotourism industry in Way Bekhak continues, it can always be used by the community to achieve prosperity. Of course, the development of ecotourism must be based on people's principles, namely the development of sustainable ecotourism based on the interests of the community.
In addition, the private sector as an important part of running the economy must still be involved. The improvement of the sustainable ecotourism industry model in Way Bekhak must always be improved. In this context, the private sector can play an important role as a driving force for the ecotourism industry. Private involvement will provide opportunities for success in increasing revenue from the ecotourism industry in Way Bekhak. In addition, the private sector can make the community a strategic partner in maintaining the ecotourism industry. In increasing the knowledge of strategic partners, the private sector will provide training or empowerment to the community on how to protect the environment or maintain ecotourism areas so that the ecotourism industry business can be sustainable.

However, the involvement of the private sector must be monitored and given rules in exploiting ecotourism areas. The realm of supervision can be taken by the government which has the authority to maintain order and the continuity of the ecotourism industry. The government can be used as an intervention agency in ensuring the sustainability of ecotourism in the Way Bekhak area. The government can make a set of regulations that the rules can be discussed with the public and the private sector, to find a rule formulation that accommodates the interests of all parties. Therefore, proportional involvement between the community, the private sector, and the government is an important thing in maintaining the sustainability of Way Bekahak ecotourism. Thus, the form of involvement between the three actors can be described as shown below:

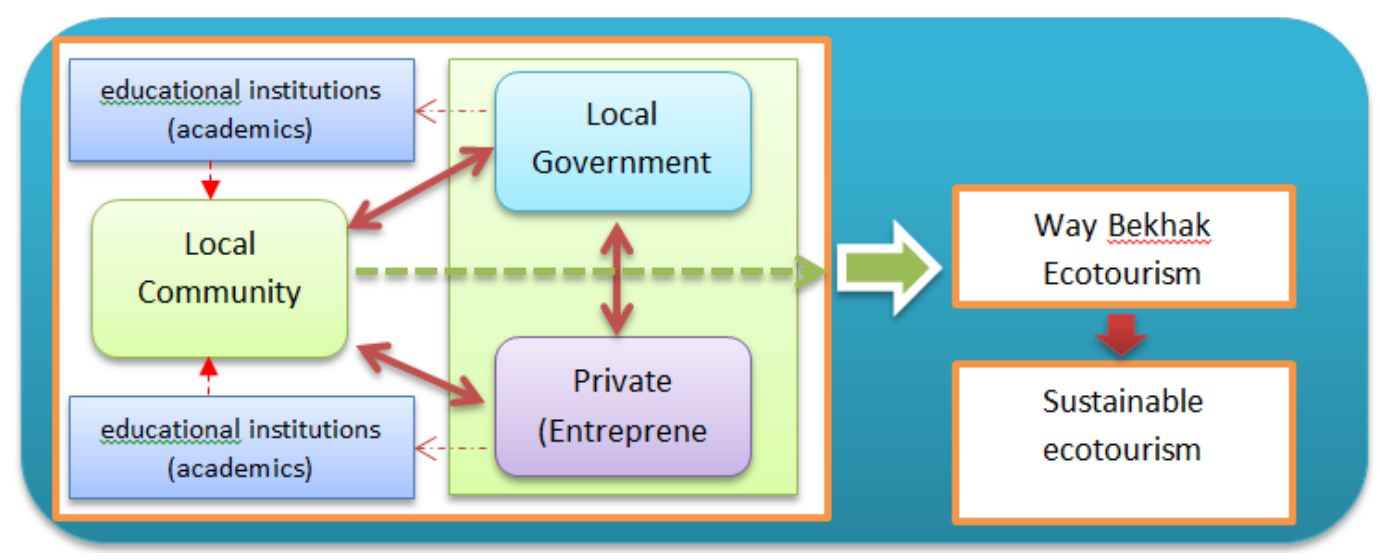

Fig. 1. Idealist model of sustainable ecotourism in the ecotourism area Way Bekhak

Communities are placed as agents of change in their area. The government and the private sector can work together in providing empowerment to the community. the implementation of this empowerment can use a third party, namely academics. This form of empowerment can be in the form of skills training and understanding related to how to manage sustainable ecotourism. The results of this empowerment must continue to be monitored for success, especially in managing ecotourism in Way Bekhak. When this knowledge in managing ecotourism is considered successful, then the community can be entrusted with managing sustainable ecotourism in Way Bekhak. When this management has been given to the community. Then the community must be able to become a direct agent in working together in determining a sustainable ecotourism industry model. Government involvement is only limited to overseeing 
sustainable ecotourism by not intervening too far. the working model of each actor (Society, Government, and Private) is regulated in a jointly made rule.

\section{ACKNOWLEDGMENT}

Acknowledgments are given to the Department of Sociology, Faculty of Social and Political Sciences, the University of Lampung for their scientific support. Thanks are also given to research institutes and services at the University of Lampung for their financial support during this research.

\section{REFERENCES}

[1] T. Soekarya. Peningkatan Ekonomi Kerakyatan Melalui Pengembangan Desa Wisata. Jakarta: Kementrian Kebudayaan dan Pariwisata. 2011.

[2] S. Arida. Ekowisata: pengembangan, partisipasi lokal, dan tantangan ekowisata. Cakra Press. 2017.

[3] O. Pontoh. Identifikasi dan analisis modal sosial dalam rangka pemberdayaan masyarakat nelayan Desa Gangga Dua Kabupaten Minahasa Utara. Jurnal Perikanan dan Kelautan. Tropis 6.3. 2010. 125-133.

[4] J. Hisbullah. Social Capital (Menuju Keunggulan Budaya Manusia Indonesia. Jakarta: Mr-United Press. 2006.

[5] Junaidi. Perubahan Sosial Dan Lingkungan Masyarakat Di Daerah Ekowisata Pantai Kuta Lombok Tengah. Bandung: Departemen Sosiologi Pascasarjana Fisip Unpad. 2018.

[6] S. N. Qodriyatun. Permasalahan, Kendala, Dan Tantangan. In R. A. Yunita, Pengembangan Pariwisata Erkelanjutan Melalui Ekowisata Pengembangan Pariwisata Berkelanjutan Melalui Ekowisata Di Kawasan Konservasi (Pp. 1-43). Jakarta : Pusa Penelitian Badan Keahlian Dpr Ri; Intrans Publishing, Anggota Ikapi Jawa Timur. 2018

[7] D. Winingsih. Strategi Pengembangan Pariwisata Berkelanjutan Melalui Ekowisata Guna Mendorong Kemandirian Ekonomi Masyarakat (Studi Kasus Pada Lokawisata Baturaden). Purwokerto: Jurusan Ekonomi Syariah Fakultas Ekonomi Dan Bisnis Islam Institut Agama Islam Negeri Purwokerto. 2020.

[8] M. R. Lubis. Peran Pemuda Dalam Pengelolaan Ekowisata Melalui Lembaga Pariwisata Tangkahan (Studi Pada Kawasan Ekowisata Tangkahan, Desa Namu Sialang, Kecamatan Batang Serangan, Kabupaten Langkat). Medan: Sekolah Pascasarjana Universitas Sumatera Utara. 2018.

[9] J. T. Haryanto. Pariwisata Berkelanjutan. Proceedings of the 6th International Conference of the Asian Academy of Applied Business (Aaab) 2013 (Pp. 1-11). Bandung: Asian Academy of Applied Business \& Universiti Malaysia Sabah. 2013. Retrieved Https://Www.Ums.Edu.My/Fpep/Files/Tour04_2013.Pdf

[10] Y. E. Febriana \& E. Pangestuti. Analisis Dampak Pengembangan Kepariwisataan dalam Menunjang Keberlanjutan Ekonomi dan Sosial Budaya Lokal Masyarakat (Studi pada Desa Wisata Gubugklakah, Kecamatan Poncokusumo, Kabupaten Malang). Jurnal Administrasi Bisnis (Jab), 61(4), 143-150. 2018. Retrieved from Administrasibisnis.Studentjournal.Ub.Ac.Id

[11] M. A. Sutiarso. Pengembangan Pariwisata Yang Berkelanjutan Melalui Ekowisata. Focus Group Discussion (Fgd) Pengelolaan Teluk Bone Bidang. Kolaka: Pengelolaan Teluk Bone Bidang. 2017. 1-11.

[12] I. M. B. Wisnawa, A. A. R. Wijayanti, \& S. Jokosaharjo. Tourists expectation and perception toward Sangeh tourism village. Journal of Sustainable Tourism, 5(2). 2019. 218-227.
[13] P. S. Utari \& I. M. Kampana. Perencanaan Fasilitas Pariwisata (Tourism Amenities) Pantai Pandawa Desa Kutuh Kuta Selatan Badung. Jurnal Destinasi Pariwisata, 2(1). 2014. 57-67.

[14] A. Khairunnisa. Implementasi Pariwisata Berkelanjutan Dan Dampaknya Terhadap Pembangunan Ekonomi Masyarakat Perspektif Islam (Studi Di Desa Pujo Kidul, Kecamatan Pujon, Kabupaten Malang. Malang: Program Magister Ekonomi Syariah Pascasarjana Uin Maulana Malik Ibrahim. 2020.

[15] B. Situngkir, Z. Lubis, \& A. Kadir. Peluang Pelaksanaan Manajemen Kolaboratif Dalam Pengembangan Kawasan Situs Kota Cina Sebagai Potensi Pariwisata Di Kota Medan. $\begin{array}{lll}\text { Perspektif, } & 9(2) . & 2020 .\end{array}$ Doi:Https://Doi.Org/10.31289/Perspektif.V9i2.3295

[16] E. Andina. Tantangan Implementasi Daya Dukung Sosial Pada Kawasan Ekowisata. In R. A. Yunita, Pengembangan Pariwisata Berkelanjutan Melalui Ekowisata (Pp. 47-72). Jakarta: Pusat Penelitian Badan Keahlian Dpr Ri; Intrans Publishing, Anggota Ikapi Jawa Timur. 2018.

[17] E. Durkheim. Moral education. Courier Corporation. 2012.

[18] G. Ritzer. Teori Sosiologi: Dari sosiologi klasik sampai perkembangan terakhir postmodern. Yogyakarta: Pustaka Pelajar. 11. 2012. 25.

[19] V. Bartkus, \& J. Davis. Social Capital: Reaching Out, Reaching In,. Northampton, Ma.: Edward Elgar Publishing. 2009. Doi: $10.4337 / 9781848445963$

[20] E. Bueno, M. Salmador, \& O. Rodríguez. The Role Of Social Capital In Today's Economy: Empirical Evidence And Proposal Of A New Model Of Intellectual Capital. Journal Of Intellectual Capital, 5(4), 2007. 556-574.

[21] A. Cloete. Social Cohesion And Social Capital: Possible Implications For The Common Good. Verbum Et Ecclesia, 35(3), 2014. 1-6. Doi:10.4102/Ve.V35i3.1331

[22] R. Lewicki, \& C. Brinsfield. Trust And Distrust And Building Social Capital', In (Eds.), , Pp. In V. Bartkus, \& J. Davis, Social Capital: Reaching Out, Reaching In (Pp. 275-303). Northampton, Ma.: Edward Elgar Publishing Limited. 2009. Doi: $10.4337 / 9781848445963.00022$

[23] R. Putnam. Bowling Alone: The Collapse And Revival Of American Community. Princeton.: University Press. 2000.

[24] Oecd. The Well-Being Of Nations. The Role Of Human And Social Capital. Paris: Oecd. 2001.

[25] J. Nahapiet, \& S. Ghosal. Social Capital, Intellectual Capital And The Organizational Advantage. Academy Of Management Review, 23(2), 1998. 242-266.

[26] J. S. Coleman. Social Capital In The Creation Of Human Capital. American Journal Of Sociology, 94, 1988. S95-S120.

[27] J. S. Coleman. Foundations Of Social Theory. Cambridge: Harvard University Press. 1990.

[28] F. Herreros. The Problem Of Forming Social Capital: Why Trust? Houndsmill: Palgrave Macmillian. 2004. Doi: $10.1057 / 9781403978806$

[29] P. Spoonley, R. Peace, A. Butcher, \& D. O'neill. Social Cohesion: A Policy And Indicator Framework For Assessing Immigrant And Host. Social Policy Journal Of New Zealand (24). 2005. 85-110.

[30] G. P. Requena, M. Ortega, \& P. Villaverde. Towards Pioneering Through Capabilities In Dense And Cohesive Social Networks. Journal Of Business \& Industrial Marketing, 27(1). 2012. 41-56.

[31] S. N. Mulunga, \& R. Yazdanifard. Review Of Social Inclusion, Social Cohesion And Social Capital In Modern. Organization Global Journal Of Management And Business Research: A Administration And Management, 14(3). 2014. 15-20.

[32] D. Schugurensky. Civic Participation. On Active Citizenship, Social Capital And Public Policy. Canadian Diversity, 2(1), 2003. 10-12.

[33] Rostin. The Effect Of Economic Empowerment Of The Coastal Communities And Social Capital On Coastal Community 
Welfare. The International Journal Of Engineering And Science (Ijes), 5(2). 2016. 12-18.

[34] F. Fukuyama. Trust: The Social Virtues And The Creation Of Prosperity. New York: Free Press. 1995.

[35] A. Dalem. Ekowisata : Konsep Dan Implementasinya Di Bali. Jurnal Ilmiah Dinamika Kebudayaan, V(3). 2002. 109-114.
[36] K. Lindberg. Tourism as a Development Path in The South, presented at the Conference of Tourism in North/South Perspectives organized by the North/South Coalition and Forum. 2002. 